
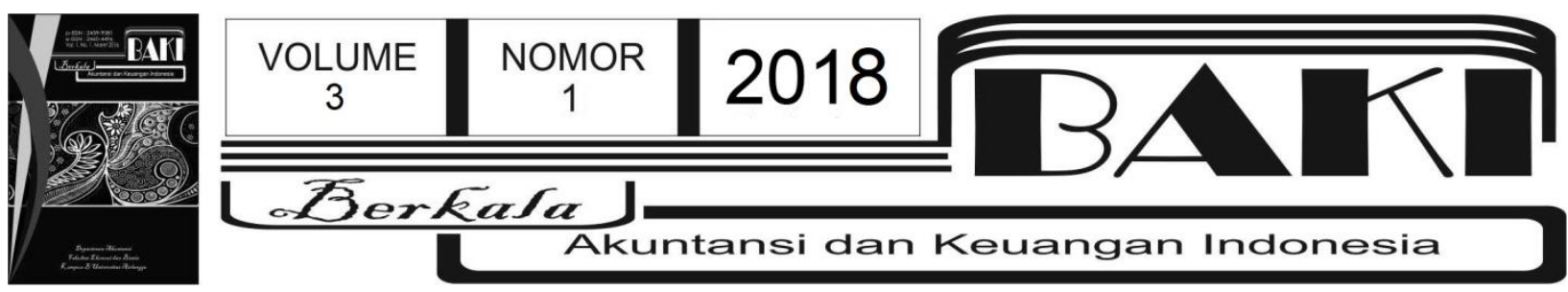

\title{
Pengaruh Persepsi Wajib Pajak Orang Pribadi Pekerjaan Bebas Atas Tax rate dan Penalty rate Terhadap Tax evasion (Studi Empiris: Kpp Mulyorejo)
}

\author{
Mujahid Ma'ruf ${ }^{1,2}$ \\ Elia Mustikasari ${ }^{1}$ \\ ${ }^{1}$ Universitas Airlangga \\ 2samumaruf94@gmail.com
}

\section{INFO ARTIKEL}

Histori Artikel:

Tanggal Masuk 27 Februari 2018

Tanggal Diterima 29 Maret 2018

Tersedia Online 31 Maret 2018

Kata Kunci:

perception; tax evasion; tax

rate; tax penalty

\begin{abstract}
A B STRAK
Tujuan penelitian ini adlaah untuk mengeksplorasi persepsi wajib pajak orang pribadi pekerjaan bebas atas tax rate dan penalty rate terhadap tax evasion. Variabel dependen dalam penelitian ini adalah persepsi mengenai tax evasion sedangkan variabel independen dalam penelitian ini adalah persepsi mengenai tax rate dan penalty rate. Responden dalam penelitian ini adalah wajib pajak orang pribadi yang telah memiliki NPWP. Sebanyak 100 responden telah mengisi kuesioner yang telah disebarkan. Analisis data menggunakan multiple linear regression dengan bantuan aplikasi SPSS. Hasil penelitian menunjukkan bahwa persepsi mengenai tax rate berhubungan positif dengan persepsi tax evasion, sedangkan persepsi mengenai penalty rate berhubungan negatif dengan persepsi tax evasion.
\end{abstract}

\section{Pendahuluan}

Populasi penduduk yang meningkat menjadikan negara Indonesia menjadi salah satu negara dengan kepadatan penduduk tertinggi di dunia dengan jumlah penduduk mencapai 258.316.051 jiwa per 4 november 2016 dan menduduki peringkat ke 4 negara dengan populasi terbanyak di dunia. Hal ini menandakan bahwa negara Indonesia yang menjadi salah satu negara dengan populasi terbanyak di dunia seharusnya banyak melakukan pembangunan secara merata baik dari segi Pendidikan, kesehatan, keamanan, dan infrastruktur. Indonesia yang secara geografis memiliki banyak pulau menjadikan pembangunan infrastruktur menjadi 
penting karena harus dilaksanakan secara merata dan berkualitas dan pembangunan yang holistik ini membutuhkan dana yang tidak sedikit.

Pembangunan yang akan dilaksanakan oleh negara memerlukan dana yang banyak dan sumber dana negara Republik Indonesia adalah dari anggaran pendapatan dan belanja negara (APBN). Komposisi dari APBN mayoritas berasal dari pendapatan dari sektor pajak. Pajak merupakan elemen yang fundamental dalam proyeksi pembangunan di negeri ini sehingga seharusnya pendapatan dari sektor fiskal ini dapat dioptimalkan. Pentingnya pajak bagi negara sangat disesalkan apabila masyarakat itu sendiri belum menyadarinya. Ada sebagian dari masyarakat baik itu orang pribadi ataupun badan masih kurang perhatian pada pembangunan negara sehingga mereka tidak terlalu memedulikan tentang pembayaran pajak. Baik orang pribadi ataupun badan dalam membayar pajak biasanya berusaha mengeluarkan pajak seminimal mungkin. Sebagian dari para pengusaha atau orang pribadi yang memiliki keahlian hanya berorientasi pada profit sehingga wajib pajak melupakan bahwa sebenarnya memiliki kapasitas untuk memberikan kontribusi yang nyata bagi negara dengan membayar pajak. Wajib pajak dituntut untuk melakukan efisiensi semaksimal mungkin dengan menekan angka - angka beban atau cost menjadi seminimal mungkin. Salah satu pos yang dapat ditekan adalah beban pajak.

Menurut Suandy (2011:21) pajak dapat ditekan dengan dua cara yaitu penghindaran pajak (tax avoidance) dan penggelapan pajak (tax evasion). Penghindaran pajak (tax avoidance) adalah suatu usaha pengurangan secara legal yang dilakukan dengan cara memanfaatkan ketentuan-ketentuan di bidang perpajakan secara optimal seperti pengecualian dan pemotongan-pemotongan yang diperkenankan maupun manfaat hal-hal yang belum diatur dan kelemahan-kelemahan yang ada dalam peraturan perpajakan yang berlaku (Suandy, 2011: 21).

Penggelapan pajak (tax evasion) adalah upaya pengurangan pajak yang dilakukan dengan melanggar peraturan perpajakan seperti memberi data-data palsu atau menyembunyikan data (Suandy, 2011). Penggelapan pajak dapat dikenakan sanksi pidana (Suandy, 2011: 21). Penggelapan pajak juga dapat berupa usaha - usaha untuk memperkecil jumlah pajak yang terutang atau menggeser beban pajak yang terutang dengan melanggar ketentuan - ketentuan pajak yang berlaku. Tax evasion merupakan pelanggaran dalam bidang perpajakan dan pelaku dari tax evasion dapat dikenakan sanksi baik secara administratif maupun berupa sanksi pidana.

Tax evasion ini memiliki beberapa efek yang tidak baik bagi perekonomian negara kedepannya. Menurut Johnson et al., (2000) penggelapan pajak lebih mungkin dapat memperlambat pertumbuhan ekonomi seperti kemampuan pemerintah untuk menyediakan barang publik yang memadai, lembaga penunjang pasar, infrastruktur, pengembangan sumber daya manusia, atau penelitian dan pengembangan akan melemah. 
Ada banyak hal yang dapat mendorong wajib pajak baik wajib pajak orang pribadi maupun wajib pajak badan untuk melakukan tax evasion, diantaranya tax rate dan penalty rate. Dua hal tersebut sesuai dengan penelitian dari Allingham dan Sandmo (1972) yang berfokus pada pengaruh tax rate dan penalty rate terhadap tax evasion.

Tax rate merupakan tarif yang ditetapkan atas penghasilan kena pajak untuk menghitung pajak penghasilan yang terutang. Tarif ini telah ditetapkan dalam Undang - Undang Ketentuan Umum Perpajakan (KUP). Tarif pajak ini merupakan prosentase pajak yang harus dibayarkan oleh wajib pajak. Dalam penelitian sebelumnya, Yalama (2013) dan Misman et al., (2013) menyatakan bahwa tax rate memiliki pengaruh positif terhadap tax evasion. Namun ada pula penelitian dari Joulfaian (2009) yang menyatakan bahwa tax rate memiliki pengaruh yang negatif terhadap tax evasion.

Penalty rate merupakan tarif denda yang telah ditetapkan dalam Undang - Undang Ketentuan Umum Perpajakan sebagai kompensasi pada wajib pajak yang melakukan kesalahan ataupun keterlambatan baik dalam pelaporan maupun pembayaran secara disengaja maupun tidak disengaja.

Menurut Evaldas dan Linas (2015) menyatakan bahwa penalty rate juga berpengaruh pada tax evasion. Hal ini mendukung penelitian dari Misman et al., (2013) bahwa salah satu determinant dari tax evasion adalah tarif sanksi serta Hasseldine et al. (2007) yang menyatakan bahwa penalty rate mempengaruhi tax evasion secara negatif. Namun ada pula penelitian dari Ameyaw et al., (2015) yang menyatakan bahwa penalty rate tidak berpengaruh terhadap tax evasion.

Berdasarkan latar belakang yang telah dijelaskan, maka rumusan masalalah pada penelitian ini adalah: apakah persepsi wajib pajak orang pribadi pekerjaan bebas atas tax rate dan penalty rate berpengaruh terhadap tax evasion? Tujuan yang ingin dicapai dalam penyusunan penelitian ini adalah untuk mengetahui apakah persepsi wajib pajak orang pribadi pekerjaan bebas atas tax rate dan penalty rate berpengaruh terhadap tax evasion.

\section{Tinjauan Pustaka}

\subsection{Teori Keagenan}

Jensen dan Meckling (1976) mendeskripsikan hubungan keagenan merupakan kumpulan kontrak (nexus of contract) dimana satu atau lebih orang (prinsipal) memerintah orang lain (agen) untuk melakukan suatu jasa atas nama principal serta memberi wewenang kepada agen untuk membuat keputusan yang terbaik bagi prinsipal. 


\subsection{Teori Persepsi}

Walgito (2004) mengungkapkan bahwa persepsi merupakan suatu proses pengorganisasian, penginterprestasikan terhadap stimulus yang diterima oleh organisme atau individu sehingga menjadi sesuatu yang berarti, dan merupakan aktivitas yang terintegrasi dalam diri individu.

\subsection{Pengaruh Tax rate terhadap Tax evasion}

Tax rate merupakan tarif yang ditetapkan atas penghasilan kena pajak untuk menghitung pajak penghasilan yang terutang. Tarif pajak yang berlaku apabila mengalami kenaikan, maka wajib pajak akan mengalami kenaikan prosentase pembayaran kewajiban pajaknya dan menaikkan beban pajak yang seharusnya wajib pajak bayar. Hal ini akan mempengaruhi pemikiran dari wajib pajak dikarenakan wajib pajak akan merasa memiliki beban yang berlebih untuk membayar utang pajaknya, dan menyebabkan wajib pajak memiliki kecenderungan untuk melakukan penggelapan pajak.

Penelitian yang dilakukan oleh Misman et al., (2013) dan penelitian yang dilakukan oleh Yalama dan Gumus (2013), membuktikan bahwa tax rate dapat mempengaruhi tax evasion. Sehingga dapat diajukan hipotesis sebagai berikut:

\section{H1 : Tax rate berpengaruh positif terhadap tax evasion.}

\subsection{Pengaruh Penalty rate terhadap Tax evasion}

Penalty rate merupakan tarif sanksi yang telah ditetapkan dalam undang - undang ketentuan umum perpajakan sebagai kompensasi pada wajib pajak baik orang pribadi maupun badan yang melakukan kesalahan ataupun keterlambatan baik dalam pelaporan SPT maupun pembayaran secara disengaja maupun tidak disengaja.

Dengan diketahuinya sanksi baik sanksi bunga maupun sanksi denda ataupun kenaikan maka akan menjadi pertimbangan tersendiri bagi para manajemen perusahaan ataupun pengusaha apabila ingin melakukan penggelapan pajak karena apabila hal tersebut dilakukan, maka kemungkinan untuk terdeteksi tetap cukup besar dan bila terdeteksi maka pelaku penggelapan pajak akan memiliki kewajiban lebih untuk membayar utang pajaknya dan juga denda atau sanksi yang diperoleh. Tentu saja hal ini ditambah dengan reputasi pelaku tax evasion akan jelek di mata relasi dan mitra bisnis pelaku. Penelitian terdahulu tentang penalty rate telah dilakukan oleh Misman et al., (2013) yang menyatakan bahwa fine rate akan berpengaruh terhadap tax evasion. Meningkatnya penalty rate akan berpengaruh pada penurunan tax evasion yang ada. Karena dengan naiknya penalty rate merupakan tindakan 
preventif untuk mencegah praktek tax evasion. Berdasarkan penjelasan diatas, maka penulis mengemukakan hipotesis sebagai berikut:

\section{H2 : Penalty rate berpengaruh negatif terhadap tax evasion}

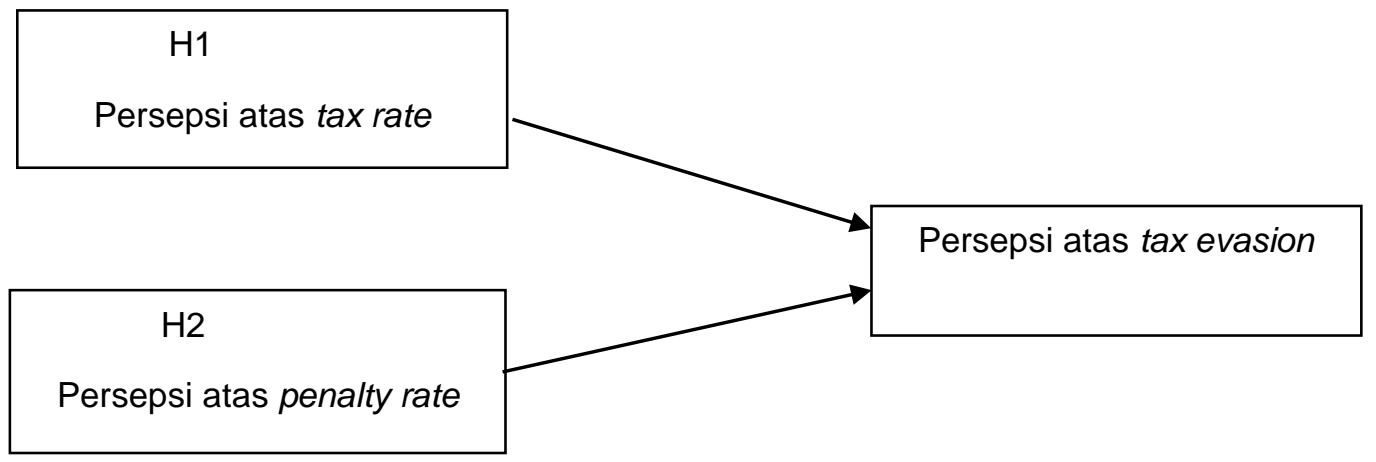

\section{Gambar 1: Kerangka Konseptual Penelitian}

\section{Metodologi Penelitian}

\subsection{Pendekatan Penelitian}

Penelitian ini dilakukan menggunakan pendekatan kuantitatif dengan jenis penelitian eksplanasi. Pendekatan kuantitatif menitikberatkan pada pengujian hipotesis, data yang digunakan harus terukur, dan akan menghasilkan kesimpulan yang dapat digeneralisasikan, serta pendekatan ini memiliki tujuan yang mengarah pada hasil generalisasi, menjelaskan fenomena secara lebih terukur, dan adanya pembuktian (Airlangga, 2009:14). Penelitian eksplanasi adalah penelitian yang menemukan dan menjelaskan kedudukan variabel-variabel yang diteliti serta hubungan antara satu variabel dengan variabel lainnya (Anshori dan Iswati, 2009:12).

\subsection{Definisi Operasional Variabel}

Persepsi atas tax evasion adalah persepsi dari wajib pajak atas upaya pengurangan pajak yang dilakukan dengan melanggar peraturan perpajakan seperti memberi data - data palsu atau menyembunyikan data. Dengan demikian penggelapan pajak dapat dikenakan sanksi pidana (Suandy, 2011:21). Garbarino (2011) menyatakan bahwa penggelapan pajak adalah perilaku yang disengaja melibatkan pelanggaran langsung dari hukum pajak dalam rangka untuk melarikan diri dari pembayaran pajak. Tax evasion juga dapat berupa usaha usaha untuk memperkecil jumlah pajak yang terutang atau menggeser beban pajak yang terutang dengan melanggar ketentuan - ketentuan pajak yang berlaku. Indikator dari tax 
evasion ini adalah bentuk - bentuk dari praktik penggelapan pajak seperti mengecilkan laba fiskal dengan tidak mengakui sebagian pendapatan, mengecilkan laba fiskal dengan membesarkan biaya, menggunakan dokumen palsu, dan mengkreditkan yang tidak seharusnya dan dengan menggunakan skala Likert

Persepsi atas tax rate adalah persepsi dari wajib pajak atas ukuran dari beban pajak menurut usaha yang dilakukan oleh wajib pajak, baik wajib pajak orang pribadi maupun wajib pajak badan. Tax rate merupakan tarif yang ditetapkan atas penghasilan kena pajak untuk menghitung pajak penghasilan yang terutang. Tarif ini telah ditetapkan di dalam Undang Undang Ketentuan Umum Perpajakan. Tarif pajak ini merupakan prosentase pajak yang harus dibayarkan oleh wajib pajak. Indikator dalam tax rate ini adalah item - item dalam Undang Undang PPh pasal 17 dengan menggunakan skala Likert.

Persepsi atas penalty rate adalah persepsi wajib pajak atas ukuran dari beban pajak tambahan bagi wajib pajak yang melakukan kesalahan atau kekeliruan yang dilakukan baik secara tidak sengaja maupun secara sengaja. Penalty rate merupakan tarif denda yang telah ditetapkan dalam Undang - Undang Ketentuan Umum Perpajakan sebagai kompensasi pada wajib pajak yang melakukan kesalahan ataupun keterlambatan baik dalam pelaporan maupun pembayaran secara disengaja maupun tidak disengaja. Indikator dalam penalty rate ini adalah item - item yang ada pada Undang - Undang KUP mengenai sanksi baik denda, bunga maupun kenaikan dengan menggunakan skala Likert.

\subsection{Populasi dan Sampel}

Dalam penelitian ini, populasi yang digunakan adalah wajib pajak orang pribadi pekerjaan bebas yang telah memiliki NPWP dan telah melakukan pembayaran pajak minimal selama 1 tahun pada tahun 2016 yang berada di KPP Mulyorejo dengan jumlah 18.244 orang. Dalam penelitian ini, pemilihan sampel yang digunakan oleh peneliti adalah menggunakan metode accidental sampling. Accidental sampling atau convenience sampling merupakan teknik sampling dimana sampel diperoleh ketika responden tepat berada di lokasi penelitian ketika dilangsungkannya pengambilan data dan sesuai dengan kebutuhan penelitian. Dengan menggunakan rumus slovin, maka total sampel penelitian sebanyak 100 responden.

\subsection{Jenis dan Sumber Data}

Jenis data yang digunakan dalam penelitian ini adalah data kuantitatif. Data kuantitatif dapat diolah dan dianalisis dengan menggunakan teknik perhitungan secara matematis atau statistika. Sumber data yang digunakan dalam penelitian adalah data primer. Data primer 
merupakan data utama penelitian yang berasal atau bersumber dari hasil kuesioner atas data data akuntansi serta data - data perpajakan yang merupakan obyek penelitian.

\subsection{Prosedur Pengumpulan Data}

Prosedur pengumpulan data dalam penelitian ini dilakukan dengan langsung karena menggunakan kuesioner sebagai alat untuk memperoleh data yang diinginkan. Data kuesioner yang dikumpulkan tersebut digunakan untuk dapat menjawab rumusan masalah yang telah dirumuskan dalam penelitian yaitu digunakan untuk mengetahui apakah persepsi wajib pajak orang pribadi atas tax rate dan penalty rate berpengaruh terhadap tax evasion.

\subsection{Model dan Teknik Analisis}

Model analisis yang digunakan dalam penelitian adalah regresi linear berganda. Penggunaan regresi linier berganda dilakukan untuk mengukur hubungan antara variabel independen yakni persepsi atas tax rate $\left(\mathrm{X}_{1}\right)$ dan persepsi atas penalty rate $\left(\mathrm{X}_{2}\right)$ dengan variabel dependen yakni tax evasion. Uji hipotesis ini dilakukan mengunakan program SPSS versi 18 dan model regresi linier berganda diformulasikan sebagai berikut:

$$
Y=a+\beta_{1} X_{1}+\beta_{2} X_{2}+e
$$

Teknik analisis yang digunakan dalam penelitian ini adalah pengujian kualitas data yang terdiri dari uji reliabilitas dan uji validitas, uji asumsi klasik yakni terdiri dari uji normalitas, uji multikolinieritas, dan uji heterokedastisitas. Lalu pengujian hipotesis dilakukan dengan menggunakan uji koefisien determinasi dan uji statistik t.

\section{Analisis dan Pembahasan}

\subsection{Uji Reliabilitas}

Uji reliabilitas digunakan untuk mengetahui keandalan (konsistensi) instrumen (alat ukur) berupa kuisioner dalam suatu penelitian dengan menggunakan tekhnik Cronbach's Alpha, yakni menghitung koefisien alpha. Reliabilitas instrumen diukur dengan mengkorelasikan skor masing-masing butir pertanyaan pada setiap variabel. Nilai reliabilitas merupakan kombinasi dari skor-skor korelasi tersebut 
Tabel 1. Uji Reliablitias

\begin{tabular}{|ccc|}
\hline Variabel & Alpha Cronbach & Keterangan \\
\hline Persepsi atas Tax rate & 0.888 & Reliabel \\
Persepsi atas Penalty rate & 0.956 & Reliabel \\
Tax evasion & 0.876 & Reliabel \\
\hline
\end{tabular}

Sumber: Data diolah, 2017.

Hasil perhitungan menunjukkan nilai alpha cronbach mempunyai nilai lebih besar dari 0,6 sehingga seluruh variabel bebas yaitu persepsi atas tax rate dan penalty rate dan terikat yaitu tax evasion dinyatakan mempunyai reliabilitas yang baik.

\subsection{Uji Validitas}

Uji validitas ini bertujuan untuk menguji sejauh mana ketepatan dan kecermatan suatu alat ukur dalam melakukan fungsi ukurnya. Pengujian ini dilakukan dengan cara mengkorelasikan antara skor item dengan skor total variabel setelah skor total dikurangi dengan indikator. Koefisien korelasi yang tinggi menunjukkan kesesuaian antara fungsi item dengan penelitian secara keseluruhan. Data yang diuji sebanyak 100 responden dengan menggunakan SPSS 18.

Tabel 2. Uji Validitas Variabel Persepsi atas Tax evasion

\begin{tabular}{|cccc|}
\hline Variabel & Indikator & R & Keterangan \\
\hline \multirow{3}{*}{ Tax evasion } & Y1.1 & 0.728 & Valid \\
& Y1.2 & 0.669 & Valid \\
& Y1.3 & 0.747 & Valid \\
& Y1.4 & 0.795 & Valid \\
\hline
\end{tabular}

Sumber: Data diolah, 2017.

Tabel 2 dan 3 menunjukkan bahwa item - item pertanyaan pada variabel persepsi atas tax evasion, tax rate dan penalty rate dikatakan valid karena nilai koefisien korelasi antara item dan total item $>0,3$. Dengan demikian seluruh item pertanyaan dari tax evasion mampu mengukur variabel tax evasion. Atas dasar tersebut maka seluruh item memenuhi syarat validitas dan akan tetap dipertahankan dalam skala dan dipergunakan dalam analisis selanjutnya.

Tabel 3. Uji Validitas Variabel Persepsi atas Tax rate dan Penalty rate

\begin{tabular}{|cccc|}
\hline Variabel & Indikator & R & Keterangan \\
\hline \multirow{4}{*}{ Tax rate } & X1.1 & 0.592 & Valid \\
& X1.2 & 0.823 & Valid \\
& X1.3 & 0.842 & Valid \\
X1.4 & 0.776 & Valid \\
\hline & X2.1 & 0.757 & Valid \\
X2.2 & 0.765 & Valid \\
X2.3 & 0.817 & Valid \\
\hline
\end{tabular}




\begin{tabular}{|cccc|}
\hline Variabel & Indikator & R & Keterangan \\
\hline & X2.4 & 0.782 & Valid \\
X2.5 & 0.811 & Valid \\
X2.6 & 0.816 & Valid \\
& X2.7 & 0.733 & Valid \\
& X2.8 & 0.739 & Valid \\
Xenalty rate & X2.10 & 0.667 & Valid \\
& X2.11 & 0.803 & Valid \\
& X2.12 & 0.780 & Valid \\
& X2.13 & 0.612 & Valid \\
& X2.14 & 0.742 & Valid \\
& X2.15 & 0.686 & Valid \\
& X2.16 & 0.696 & Valid \\
& 0.683 & Valid \\
\hline
\end{tabular}

Sumber: Data diolah, 2017.

\subsection{Uji Statistik $t$}

Uji statistik t pada dasarnya menunjukkan seberapa jauh pengaruh satu variabel independen secara individual dalam menerangkan variasi variabel dependen (Ghozali, 2006:84). Berdasarkan hasil yang ada pada tabel 6 di atas, dapat dikatakan bahwa hipotesis pertama $(\mathrm{H} 1)$ dalam penelitian ini yang menyatakan persepsi atas tax rate berpengaruh terhadap tax evasion adalah terbukti dan diterima. Hal tersebut dapat dilihat berdasarkan nilai signifikasi hitung (Sig) sebesar 0,001 < tingkat kepercayaan 0,05 (5\%); Hipotesis kedua (H2) dalam penelitian ini yang menyatakan persepsi atas penalty rate berpengaruh terhadap tax evasion adalah terbukti dan diterima. Hal tersebut dapat dilihat berdasarkan nilai signifikasi hitung (Sig) sebesar 0,012 < tingkat kepercayaan 0,05 (5\%);

\section{Analisis dan Pembahasan}

\subsection{Pengaruh Persepsi Wajib Pajak Orang Pribadi atas Tax rate terhadap Tax evasion}

Hipotesis pertama pada penelitian ini yakni persepsi atas tax rate berpengaruh positif terhadap tax evasion. Hasil penelitian menunjukkan bahwa dengan naiknya tarif pajak atau dengan kata lain tingginya tarif pajak yang berlaku akan menyebabkan wajib pajak cenderung untuk melakukan tindakan penggelapan pajak dikarenakan dengan prosentase tarif pajak yang tinggi yang dikenakan untuk pendapatan yang diterima oleh wajib pajak maka beban pajak yang akan ditanggung oleh wajib pajak akan meningkat dan hal ini akan menjadi pertimbangan tersendiri bagi wajib pajak, sehingga wajib pajak mengambil resiko dengan melakukan praktik penggelapan pajak dikarenakan beban pajak yang akan dikeluarkan dengan berdasarkan prosentase tarif pajak yang tinggi lebih banyak daripada biaya resiko dari terungkapnya praktik penggelapan pajak yang akan dilakukan. 
Hal ini sesuai dengan penelitian yang ada yakni dari Clotfelter (1983) dan Mason dan Calvin (1984) yang menemukan bahwa tarif pajak memiliki pengaruh yang positif dengan penggelapan pajak. Misman et al., (2013) juga menemukan bahwa terdapat pengaruh antara tax rate dan tax evasion. Pengaruh terhadap kedua variabel ini juga berhubungan secara positif.

Tarif pajak yang berlaku apabila diasumsikan tinggi oleh wajib pajak orang pribadi maka terdapat beban yang dirasakan terlalu berlebihan oleh wajib pajak orang pribadi. Hal ini akan mengurangi pendapatan bersih yang dimiliki, sehingga terdapat kecenderungan dari wajib pajak orang pribadi untuk melakukan penggelapan pajak. Hal ini dikarenakan apabila wajib pajak orang pribadi melakukan penggelapan pajak, maka wajib pajak tidak perlu membayar lebih beban pajak yang dikeluarkan walaupun hal ini terdapat resiko untuk terdeteksi oleh pihak fiskus.

Biaya resiko dari penggelapan pajak tersebut diasumsikan oleh wajib pajak sepadan daripada diperuntukkan membayar lebih beban pajak yang akan wajib pajak orang pribadi bayarkan. Hasil penelitian di lapangan juga terbukti dan sesuai dengan teori yang ada dengan garis besar bahwa dengan tingginya tarif pajak yang berlaku maka akan tinggi pula kecenderungan wajib pajak untuk melakukan penggelapan pajak.

\subsection{Pengaruh Persepsi Wajib Pajak Orang Pribadi atas Penalty rate terhadap Tax evasion}

Hipotesis yang kedua dalam penelitian ini adalah persepsi atas penalty rate berpengaruh negatif terhadap tax evasion. Hasil penelitian menunjukkan bahwa dengan rendahnya tarif sanksi yang berlaku akan menyebabkan wajib pajak cenderung untuk melakukan tindakan penggelapan pajak dikarenakan dengan rendahnya prosentase tarif sanksi yang berlaku maka biaya resiko untuk melakukan penggelapan pajak termasuk rendah dan lebih menguntungkan untuk dilakukan.

Hasil penelitian ini juga sesuai dengan teori yang ada yakni dari Misman et al., (2013) yang menyatakan bahwa tarif sanksi memiliki pengaruh yang negatif terhadap penggelapan pajak. Hal ini didukung juga oleh Bagdigen dan Erdogan (2010) bahwa kenaikan dari tarif sanksi yang berlaku akan mendorong wajib pajak untuk tidak melakukan penggelapan pajak dan begitu juga sebaliknya bahwa tarif sanksi yang rendah akan mendorong wajib pajak untuk melakukan penggelapan pajak.

Tarif sanksi yang berlaku apabila diasumsikan rendah oleh wajib pajak maka wajib pajak akan menyepelekan konsekuensi dari praktik penggelapan pajak karena punishment yang akan diterima apabila melakukan penggelapan pajak termasuk hal yang ringan. Wajib pajak cenderung akan melakukan penggelapan pajak karena lebih menguntungkan dari sisi beban 
pajak yang dikeluarkan dan biaya resiko untuk tertangkap melakukan penggelapan pajak termasuk rendah karena tarif sanksi yang berlaku telah diasumsikan rendah.

\section{Kesimpulan, Keterbatasan dan Saran}

\subsection{Kesimpulan}

Penelitian ini meneliti tentang pengaruh persepsi wajib pajak orang pribadi pekerjaan bebas atas tax rate dan penalty rate terhadap tax evasion. Hasil penelitian ini akan disimpulkan sebagai berikut:

Hasil dari penelitian ini menunjukkan bahwa persepsi atas tax rate berpengaruh positif terhadap tax evasion. Hal ini memiliki makna bahwa dengan tingginya tarif pajak yang berlaku sebagaimana yang diasumsikan oleh wajib pajak maka wajib pajak akan cenderung melakukan penggelapan pajak. Praktik penggelapan pajak diasumsikan lebih menguntungkan bagi wajib pajak daripada membayar beban pajak yang diasumsikan tinggi oleh wajib pajak.

Persepsi atas penalty rate juga berpengaruh negatif terhadap tax evasion. Rendahnya tarif sanksi yang berlaku yang diasumsikan oleh wajib pajak akan menyebabkan wajib pajak cenderung untuk melakukan penggelapan pajak, dan sebaliknya bahwa bila tarif sanksi yang berlaku diasumsikan tinggi oleh wajib pajak maka mereka cenderung untuk tidak melakukan penggelapan pajak.

\subsection{Keterbatasan}

Dalam penelitian ini memiliki keterbatasan yakni dengan metode sampling berupa aksidental sampling maka responden yang menjadi sampel merupakan sampel yang kebetulan ada atau dijumpai di lokasi pengambilan data sehingga hasilnya tidak dapat digeneralisasi.

\subsection{Saran}

Berdasarkan dari hasil penelitian dan juga pembahasan yang telah dijabarkan sebelumnya maka dari pihak penyusun penelitian ini berusaha untuk memberikan rekomendasi dan saran yang bisa dipertimbangkan yaitu sebagai berikut :

Pemerintah sebagai regulator atau pembuat kebijakan sebaiknya lebih berhati - hati dalam membuat aturan terutama di bidang tarif perpajakan. Hal ini dikarenakan perubahan tarif perpajakan yang berlaku akan menyebabkan reaksi yang bermacam - macam dari wajib pajak, seperti melakukan penggelapan pajak ataupun yang lain. Pemerintah seharusnya menetapkan tarif yang sesuai dengan kondisi masyarakat namun juga untuk menghindari 
praktik penggelapan pajak dengan menurunkan tarif pajak yang berlaku dan meningkatkan tarif sanksi yang berlaku sebagai bentuk preventif dari penggelapan pajak.

\section{Daftar Pustaka}

Allingham, M. and A. Sandmo. 1972. "Income Tax evasion: A Theoretical Analysis." Journal of Public Economics 1, 323-338

Ameyaw, B., Addai, B., Ashalley, E., \& Quaye, I. 2015. The Effects of Personal Income Tax evasion on Socio-economic Development in Ghana: A Case Study of the Informal Sector.

Anshori, Muslich dan Sri Iswati. 2009. Buku Ajar Metodologi Penelitian Kuantitatif. Surabaya: Airlangga University Press.

Bagdigen, M., \& Erdogan, A. 2010. Vergi Uygulamaları Karşısında Mükelleflerin

Tutum ve Davranışlarının Tespiti: Zonguldak İli Örneği.Finans, Politik \& EkonomikYorumlar,47(548), 95-111.

Clotfelter, C. T. 1983. Tax evasion and Tax rates: An Analysis of Individual Returns. The Review of Economics and Statistics, 65(3), 363-373. doi: 10.2307/1924181

Departemen Pendidikan Nasional. 2008. Kamus Besar Bahasa Indonesia Pusat

Bahasa. Jakarta: PT Gramedia Pustaka Utama.

Eisenhardt, K. M. 1989. Agency theory: An assessment and review. Academy of management review, 14(1), 57-74.

Garbarino, C. 2011. Aggressive Tax Strategies and Corporate Ta X Governance:

An Institutional Approach. European Company \& Financial Law Review, 8, 277-304. http://dx.doi.org/10.1515/ecfr.2011.277.

Ghozali, Imam. 2004. Model Persamaan Struktural: Konsep dan Aplikasi

Dengan Program AMOS 19.0. Semarang: Badan Penerbit Universitas Diponegoro

Ghozali, Imam. 2005. Aplikasi Analisis Multivariate dengan program SPSS,

Badan Penerbit Universitas Diponegoro, Semarang.

Ghozali, Imam. 2011. Aplikasi Analisis Multivariate dengan program SPSS,

Badan Penerbit Universitas Diponegoro, Semarang.

Hakim, Abdul. 2001. Statistika Deskriptif untuk Ekonomi dan Bisnis, Edisi Pertama, Cetakan Pertama, Penertbit Ekonisia, Yogyakarta.

Hasseldine, J., Hite, P., James, S. and Toumi, M. 2007. "Persuasive communications: Tax compliance enforcement strategies for sole proprietors", Contemporary Accounting Research, Vol. 24, 171-194.

Hessing, D. J., Elffers, H., \& Weigel, R. H. 1988. Exploring the limits of self-

reports and reasoned action: An investigation of the psychology of tax evasion behavior. Journal of Personaity and Social Psychology, 54(3), 405-413. http://doi.org/10.1037/0022-3514.54.3.405

Jensen, M. C., \& Meckling, W. H. 1976. Theory of the firm: Managerial behavior, agency costs and ownership structure. Journal of financial economics, 3(4), 305-360. 
Johnson, S., Kaufmann, D., McMillan, J., \& Woodruff, C. 2000. Why do firms hide? Bribes and unofficial activity after communism. Journal of Public Economics, 76(3), 495-520. doi: http://dx.doi.org/10.1016/S0047-2727(99)00094-8

Joulfaian, D. 2009. "Bribes and Business Tax evasion", The European Journal of Comparative Economics, Vol. 6(2), 227-244.

Mason, R., dan Calvin, L. D. 1984. Public confidence and admitted tax evasion.

National Tax Journal, 37(4), 489-496

Misman, M., Noor, R. M., Omar, N., \& Aziz, R. A. 2013. Determinants of Tax evasion on Imported Vehicles. Procedia Economics and Finance, 7, 205-212. doi: http://dx.doi.org/10.1016/S2212-5671(13)00236-0

Otusanya, O. J. 2011. The role of multinational companies in tax evasion and tax avoidance: The case of Nigeria. Critical Perspectives on Accounting, 22(3), 316-332. doi: http://dx.doi.org/10.1016/j.cpa.2010.10.005

Oz Yalama, G., \& Gumus, E. 2013. Determinants of Tax evasion Behavior: Empirical Evidence from Survey Data. International Business and Management, 6(2), 15-23.

Richardson, M. and Sawyer, A. J. 2001. "A taxonomy of the tax compliance literature: Further findings, problems and prospects", Australian Tax Forum, Vol. 16, 137-320.

Sandmo, A. 2004. "The Theory of Tax evasion: A retrospective view", Norwegian School of Economics and Business Administration, Discussion Paper 31/04.

Stankevicius, E., \& Leonas, L. 2015. Hybrid Approach Model for Prevention of Tax evasion and Fraud. Procedia - Social and Behavioral Sciences, 213, 383-389. doi: http://dx.doi.org/10.1016/j.sbspro.2015.11.555

Suandy, Erly. 2011. Hukum Pajak, Edisi 5, Jakarta: Salemba Empat.

Sugiyono. 2006. Metodologi Penelitian Bisnis. Bandung: Alfabeta.

Sugiyono. 2008. Metode Penelitian Kunatitatif Kualitatif dan R\&D. Bandung: Alfabeta.

Torgler, B. 2006. "The Importance of Faith: Tax Moral and Religiosity",

Forthcoming in: Journal; of Economic Behavior and Organization.

Walgito, Bimo. 2004. Pengantar Psikologi Umum, Yogyakarta: Andi 